Revista Eletrônica de Direito Processual - REDP. Volume 16. Julho a dezembro de 2015

Periódico Semestral da Pós-Graduação Stricto Sensu em Direito Processual da UERJ

Patrono: José Carlos Barbosa Moreira. ISSN 1982-7636. pp. 640-663 http://www.e-publicacoes.uerj.br/index.php/redp/index

\title{
UM BREVE ESTUDO SOBRE A NATUREZA JURÍDICA DAS PRISÕES \\ CAUTELARES (?) NO PROCESSO PENAL BRASILEIRO ${ }^{1}$
}

\section{A BRIEF STUDY ABOUT THE LEGAL NATURE OF PRECAUTIONARY PRISONS (?) IN BRAZILIAN CRIMINAL PROCESS}

\author{
Tatiana Paula Cruz de Siqueira \\ Bacharel em Direito pela Universidade Federal de Juiz de \\ Fora - UFJF. Professora de Direito Processual da \\ Universidade Federal de Juiz de Fora - UFJF. Mestranda em \\ Direito Processual pela Universidade do Estado do Rio de \\ Janeiro - UERJ. \\ tatianapaulacruz@gmail.com
}

RESUMO: O presente estudo destina-se a analisar, ainda que brevemente, a natureza jurídica das prisões ditas cautelares, que ocorrem durante o inquérito policial e o processo penal. Ao longo do trabalho, serão analisadas a prisão em flagrante, a prisão preventiva, segundo cada um de seus pressupostos e, por fim, a prisão temporária. Ao final, serão apresentadas as medidas que são consideradas efetivamente cautelares, servindo à utilidade do provimento final, como medidas de segurança do procedimento, não satisfativas.

PALAVRAS-CHAVES: medida cautelar - processo penal - prisão provisória - natureza jurídica - presunção de inocência.

ABSTRACT: This article analyzes, even if soon, the legal nature of prison said as precautionary, that occur during the police investigation or criminal process. Over this study, prison in the act, preventive prison, according to each of its assumptions and, lastly, temporary prison will bel analyzed. At the end, will be presented the measures, which are

\footnotetext{
${ }^{1}$ Artigo recebido em 04/08/2015 e aprovado em 09/11/2015.
} 
Revista Eletrônica de Direito Processual - REDP. Volume 16. Julho a dezembro de 2015

Periódico Semestral da Pós-Graduação Stricto Sensu em Direito Processual da UERJ

Patrono: José Carlos Barbosa Moreira. ISSN 1982-7636. pp. 640-663 http://www.e-publicacoes.uerj.br/index.php/redp/index

effectively considered precautionary, serving to the utility of the final provision, like security measures.

KEYWORDS: precautionary measure - criminal process - provisory prison - legal nature - presumption of innocence

SUMÁRIO: 1.Estabelecendo algumas premissas necessárias 1.1. O panorama atual das prisões no ordenamento processual penal brasileiro1.2. A necessária distinção entre tutela cautelar e antecipatória. 2. A natureza jurídica das prisões provisórias 2.1. A natureza cautelar da prisão preventiva 2.2. Natureza jurídica da prisão em flagrante 2.3. A "cautelaridade" da prisão temporária 3. Ainda existem prisões efetivamente cautelares? Algumas conclusões. 4. Referências Bibliográficas.

\section{Estabelecendo algumas premissas necessárias}

\subsection{O panorama atual das prisões no ordenamento processual penal brasileiro}

Até o advento da Lei n. 12.403, de 04 de maio de 2011, o sistema cautelar brasileiro era, bastante pobre, resumindo-se à prisão cautelar ou liberdade provisória. Bottini, em artigo publicado quando da aprovação da nova lei, dizia que o sistema anterior à legislação reformadora era medíocre e permitia ao magistrado escolher, como medida acautelatória, a prisão ou nada. ${ }^{2}$

\footnotetext{
${ }^{2}$ Nas palavras do autor, ainda comentando a controvérsia sobre o uso do poder geral de cautela no processo penal: "A Redação anterior do Código Apresentava ao magistrado uma mediocre dicotomia no campo das cautelares pessoais. O Juiz não dispunha de alternativa para assegurar a ordem processual e a aplicação da lei penal a não ser a prisão preventiva. Era a prisão ou nada. Alguns Magistrados ainda lançavam mão de outros instrumentos, como a retenção de passaportes ou a proibição de frequência a determinados lugares, mas a aplicação destas cautelares inominadas sempre foi polêmica e cercada de suspeitas sobre sua legalidade." (BOTTINI, Pierpaolo Cruz. MEDIDAS CAUTELARES PENAIS (LEI 12.403/11): Novas regras para a prisão preventiva e outras polêmicas. Revista Eletrônica de Direito Penal. Ano 1. Vol. 1. N. 1. Junho/2013, p. 265). Ainda sobre a aplicação do poder geral de cautela no processo penal, Marcellus Polastri defende a possibilidade de exercê-lo para que o juiz decrete outras medidas cautelares não prisionais, evitando, assim, a decretação desnecessária de uma prisão. Contudo, o autor faz uma observação extremamente relevante: "Sempre a decretação de tais medidas deve se dar em casos excepcionais, pois a restrição de direitos só deve ser admitida em casos de extrema necessidade e na medida correra, na forma do princípio da Não Culpabilidade e, obviamente não se poderá conceder a título de cautelar atípica mais do que se alcançaria no Processo principal." (POLASTRI, Marcellus. A TUTELA CAUTELAR NO PROCESSO PENAL. 3.ed. Atlas: São Paulo, 2014. P. 85/86).
} 
Revista Eletrônica de Direito Processual - REDP. Volume 16. Julho a dezembro de 2015

Periódico Semestral da Pós-Graduação Stricto Sensu em Direito Processual da UERJ

Patrono: José Carlos Barbosa Moreira. ISSN 1982-7636. pp. 640-663 http://www.e-publicacoes.uerj.br/index.php/redp/index

Em razão dessa mediocridade do sistema, diversas decisões começaram a surgir na jurisprudência invocando o chamado poder geral de cautela, com escopo na aplicação subsidiária prevista no artigo 798 do Código de Processo Civil, impondo condições ao acusado ao longo do processo como contraponto à prisão preventiva, como, por exemplo, a restrição da locomoção através do condicionamento de passaporte ou do comparecimento periódico ao juízo ${ }^{3}$.

Conforme ensina Tourinho Filho, à semelhança do controle judiciaire, que já existia na França, criou-se, ao lado das prisões, outras medidas cautelares destinadas a tornar o encarceramento do investigado no decorrer do processo a última medida possível, em respeito, principalmente, ao princípio da presunção de inocência ${ }^{4}$.

A partir desse panorama, as prisões cautelares ganham algumas características expressas no CPP, quais sejam: a provisionalidade, a provisoriedade, excepcionalidade e proporcionalidade.

A primeira das características, a provisionalidade, encontra-se consagrada no art. 282, $\S \S 4^{\circ}$ e $5^{\circ}$ do CPP, que liga a prisão a uma situação fática, permitindo que ela desapareça logo que seu fundamento deixe de existir. Tem-se, ainda, a provisoriedade, por meio da qual se exige que a prisão tenha a menor duração possível, justamente por ser a cautelar mais restritiva prevista no diploma processual e enquanto cautelar, conforme veremos mais adiante, a prisão não pode tornar-se uma pena antecipada.

A ultima ratio da prisão também foi inserida como característica expressa no Código de Processo Penal, que prevê no artigo 282, § $6^{\circ}$, a excepcionalidade, deixando evidente a necessidade de se examinar o cabimento de outras cautelares menos gravosas antes de ser decretado o aprisionamento cautelar.

Por fim, tem-se também a proporcionalidade como fio condutor da decretação das cautelares $^{5}$, que impõe ao magistrado, principalmente, a análise da adequação da medida ao caso e da necessidade de sua decretação.

\footnotetext{
${ }^{3}$ Como exemplo dessa aplicação subsidiária do poder geral de cautela diante da inexistência de cautelares específicas no processo penal, vale conferir o julgamento proferido pelo Superior Tribunal de Justiça, no ano de 2007, segundo o qual não se configura constrangimento ilegal “o condicionamento da revogação da custódia cautelar ao comparecimento quinzenal do acusado ao juízo para assinatura de termo, ao acautelamento do passaporte e à proibição de viagens ao exterior" como condições para revogação da prisão preventiva. (STJ RHC: 20124 RJ 2006/0189332-7, Relator: Ministro FELIX FISCHER, Data de Julgamento: 13/11/2007, T5 QUINTA TURMA, Data de Publicação: DJ 10.12.2007 p. 398)

${ }^{4}$ TOURINHO FILHO, Fernando da Costa. Processo penal. 34. ed. São Paulo: Saraiva, 2012. v. 3, p. 430.

${ }^{5} \mathrm{O}$ princípio da proporcionalidade foi brilhantemente defendido por Badaró, em estudo produzido antes da Lei 12.403/2011, que merece análise. (BADARÓ, Gustavo Henrique Righi Ivahy. A prisão preventiva e a
} 
Revista Eletrônica de Direito Processual - REDP. Volume 16. Julho a dezembro de 2015

Periódico Semestral da Pós-Graduação Stricto Sensu em Direito Processual da UERJ

Patrono: José Carlos Barbosa Moreira. ISSN 1982-7636. pp. 640-663 http://www.e-publicacoes.uerj.br/index.php/redp/index

Posto o estado atual da prisão processual penal, passa-se a analisar mais detidamente a diferenciação entre as medidas cautelares e antecipatórias para que seja então possível adentrar ao cerne deste trabalho que consiste na análise da natureza jurídica das espécies de prisões "cautelares" existentes hoje no ordenamento jurídico brasileiro.

\subsection{A necessária distinção entre tutela cautelar e antecipatória}

No Estado Liberal, num momento em que ao juiz cabia apenas a tarefa de dizer o direito, nos exatos termos em que prescrevia a lei, devendo-se proteger o indivíduo de eventuais abusos dos magistrados, por óbvio não se admitiam as tutelas baseadas apenas na verossimilhança. Apenas ao final de todo procedimento, com a demonstração cabal da verdade, seria possível ao juiz afirmar o direito, "enunciar a lei"

Nos contornos da jurisdição contemporânea, é indispensável ressaltar que o jurisdicionado tem direito de acionar o Estado para ver tutelada sua pretensão. Em outros termos, pode-se afirmar que há um direito à prestação jurisdicional, que não se resume apenas à concessão do direito a quem melhor demonstre, mas exige a tutela adequada e efetiva, com garantias reais de fruição da tutela conferida.

Nesses termos, se o indivíduo tem direito à tutela do direito ${ }^{7}$, logicamente tem também o direito de, ao final, quando efetivamente demonstrar sua pretensão e vencer a lide, fruir do bem jurídico assegurado por meio do processo. Se é assim, é também direito do titular a tutela contra eventuais danos ou perigos de danos que afrontem o bem discutido. Aqui surge a real importância da tutela cautelar.

proporcionalidade: propostas de mudança. Revista da Faculdade de Direito da Universidade de São Paulo v. 103 p. 381 - 408 jan./dez. 2008).

${ }^{6} \mathrm{O}$ termo é usado por Marinoni. (MARINONI, Luis Guilherme. Do processo civil clássico à noção de direito a tutela adequada ao direito material e à realidade social. Disponível na Internet: http://www.abdpc.org.br/abdpc/artigos/Luiz\%20G\%20Marinoni\%20(9)\%20-\%20formatado.pdf. Acesso em 08 de novembro de 2006).

${ }^{7}$ Segue-se neste ponto do trabalho o conceito de jurisdição defendido por Marinoni, segundo o qual: “A teoria do processo desenvolvida no presente Curso de Processo Civil tem como bases o dever estatal de tutela aos direitos e o direito à tutela do direito material, que, na verdade, também expressam as premissas de que este Curso parte paia conceituar a jurisdição e a ação (...) A tutela cautelar é direito da parte, correlacionada com o próprio direito à tutela do direito. Em razão deste direito, a jurisdição tem o dever de dar tutela cautelar à parte que tem o seu direito à tutela do direito submetido a perigo de dano. O titular do direito ao ressarcimento, que vê o infrator se desfazer dos seus bens para futuramente não poder ser alcançado pela execução, tem ameaçado o seu direito à tutela ressarcitória, e, por isto, tem direito à tutela de segurança (cautelar) da tutela ressarcitória." (MARINONI, Luis Guilherme; ARENHART, Sergio Cruz. Curso de Processo Civil - Processo Cautelar. V. 4. 2. ed. Revista dos Tribunais: São Paulo, 2008, p. 23). 
Revista Eletrônica de Direito Processual - REDP. Volume 16. Julho a dezembro de 2015

Periódico Semestral da Pós-Graduação Stricto Sensu em Direito Processual da UERJ

Patrono: José Carlos Barbosa Moreira. ISSN 1982-7636. pp. 640-663 http://www.e-publicacoes.uerj.br/index.php/redp/index

Por muito tempo se entendeu a tutela cautelar como indispensável a assegurar o processo. Contudo, se a jurisdição tem como foco a figura do indivíduo, nada mais justo que a tutela cautelar sirva a proteger o direito do titular que demonstra razoavelmente detê-lo, para que, com o provimento final, tenha-se, não apenas um resultado para a demanda, mas um resultado efetivo e útil para ambas as partes.

A tutela cautelar é indispensável, pois a tutela jurisdicional efetiva, seguindo a visão do Professor Leonardo Greco é, ela própria, um direito fundamental ${ }^{8}$.

Marcellus Polastri ${ }^{9}$ reconhece um elemento que diferencia a tutela cautelar das tutelas de conhecimento e de execução: a prevenção. O objetivo do processo cautelar é justamente evitar a ação deletéria do tempo sobre o processo, protegendo os bens jurídicos envolvidos.

Para que se justifique a atuação da tutela cautelar é indispensável que o bem jurídico discutido esteja exposto a perigo de dano ou em situação de deterioração. Só assim é possível afirmar que existe um perigo da demora do processo, ou seja, o que há muito se conhece como periculum in mora.

Se já se disse que o escopo da jurisdição é garantir o direito ao seu titular de maneira útil e efetiva, por óbvio o provimento cautelar só será deferido se demonstrada a probabilidade e verossimilhança para que, num juízo preliminar, o juiz esteja convencido de que o direito será concedido ao requerente da cautela. Trata-se, assim, de demonstrar o fumus boni iuris.

Com base no que foi exposto é possível afirmar que ao decidir pela concessão da cautelar, o juiz funda-se em cognição sumária ${ }^{10}$, pois não detém ele todos os elementos indispensáveis a analisar profundamente o direito.

\footnotetext{
${ }^{8}$ Nas lições do autor: "No Estado Democrático Contemporâneo, a eficácia concreta dos direitos constitucional e legalmente assegurados depende da garantia da tutela jurisdicional efetiva, porque sem ela o titular do direito não dispõe da proteção necessária do Estado ao seu pleno gozo. A tutela jurisdicional efetiva é, portanto, não apenas uma garantia, mas, ela própria, também um direito fundamental, cuja eficácia irrestrita é preciso assegurar, em respeito à própria dignidade humana." (GRECO, Leonardo. Garantias Fundamentais do Processo: O Processo Justo. in Estudos de Direito Processual. Campos dos Goytacazes: Faculdade de Direito de Campos, 2005, págs.225/286).

${ }^{9}$ Nas lições do autor: "Essa é a razão de ser do Processo Cautelar, ou seja, um instrumento adequado para se evitar a incidência dos efeitos avassaladores do tempo sobre a pretensão que se visa obter através do Processo, e daí surge o Processo Cautelar como verdadeiro tertium genus, tendo, dentro de si, as funções do processo de conhecimento e de execução, mas, ainda, um outro elemento: a prevenção. " (POLASTRI, Marcellus. A TUTELA CAUTELAR NO PROCESSO PENAL. 3.ed. Atlas: São Paulo, 2014. P. 57).

${ }^{10}$ Aplica-se aqui o conceito dado pelo Professor Leonardo Greco: "Por tutela sumária se entende um conjunto de procedimentos caracterizados pela simplificação e redução das suas fases, dos requisitos, da forma e dos prazos dos atos processuais, instituídos com a finalidade de facilitar o acesso à Justiça e acelerar a obtenção do seu resultado. Há procedimentos sumários nas mais diversas modalidades de tutela jurisdicional, como a jurisdição de conhecimento, a jurisdição cautelar, a jurisdição voluntária e, em alguns países, na própria
} 
Revista Eletrônica de Direito Processual - REDP. Volume 16. Julho a dezembro de 2015

Periódico Semestral da Pós-Graduação Stricto Sensu em Direito Processual da UERJ

Patrono: José Carlos Barbosa Moreira. ISSN 1982-7636. pp. 640-663 http://www.e-publicacoes.uerj.br/index.php/redp/index

Se é assim, a conviç̧ão do juiz pode tornar-se outra diante de elementos mais profundos conferidos ao longo do processo e, desse modo, diante de qualquer fato que altere os fundamentos de existência da cautelar, pode ser que ela se mostre dispensável, devendo, pois, ser revogada no curso do litígio, antes mesmo da sentença final, o que demonstra sua temporariedade.

Para não se adentrar muito na análise das características da tutela cautelar, o que não é objeto do presente trabalho, importante passar para a observação da marca da cautelar que mais interessa a este estudo por ser justamente o que a diferencia da antecipação dos efeitos da tutela: a não satisfatividade.

Apenas identificar uma situação de perigo e a prova da verossimilhança das alegações não permite dizer se o requerente faz jus a uma tutela cautelar ou a uma medida antecipatória dos efeitos da tutela. A grande marca diferenciadora entre ambas está em perceber que apenas a tutela cautelar busca garantir a segurança do direito material discutido, permitindo que, posteriormente, seu titular venha a fruir dele de maneira útil; a antecipação da tutela, por sua vez, é buscada quando o pretenso titular do direito deseja fruir, de imediato, do bem jurídico, a tutela garante a satisfação imediata do requerente.

Um exemplo extremamente elucidativo é citado por Fredie Didier Jr., segundo o qual, numa disputa por um pedaço de carne, o pedido de que o juiz defira a colocação do corte na geladeira, para que o vencedor possa dele usufruir ao final é um pedido cautelar; já se o pedido for para extrair um bife para a alimentação imediata, tal providência é uma tutela antecipada $^{11}$.

Para corrigir o uso distorcido da tutela cautelar, no curso do processo, com o objetivo de satisfazer imediatamente o requerente, foi que o legislador reformador inseriu o artigo 273 no Código de Processo Civil, prevendo a antecipação dos efeitos da tutela sempre que,

\footnotetext{
jurisdição de execução.” (GRECO, Leonardo. Cognição sumária e coisa julgada. In: Revista Eletrônica de Direito Processual, ano 6, v.10, jul./dez.2012).

${ }^{11}$ Confira-se o exemplo na íntegra: “[...] se duas pessoas brigam por um pedaço de came, e uma delas pede ao magistrado que o ponha na geladeira, para que o vencedor possa usufruir do alimento ao final do processo, é requerer uma providência cautelar (assegura para efetivar no futuro); se o pedido for para a extração de um "bife", para propiciar alimentação imediata, estar-se-á diante de uma tutela antecipada atributiva". (DIDIER JUNIOR, Fredie; BRAGA, Paula Sarno; OLIVEIRA, Rafael. Curso de processo civil. Vol. 2, $7^{\mathrm{a}}$ ed. Salvador: Jus Podivm. 2012). O autor faz o registro de que a imagem citada é criação de Pedro Caymmi, Professor da Faculdade Rui Barbosa (BA), quando aluno de graduação de um dos autores deste volume, em setembro de 1998.
} 
Revista Eletrônica de Direito Processual - REDP. Volume 16. Julho a dezembro de 2015

Periódico Semestral da Pós-Graduação Stricto Sensu em Direito Processual da UERJ

Patrono: José Carlos Barbosa Moreira. ISSN 1982-7636. pp. 640-663 http://www.e-publicacoes.uerj.br/index.php/redp/index

havendo receio de dano irreparável ou de difícil reparação, o requerente demonstrar a plausibilidade do direito, através de um juízo de verossimilhança. ${ }^{12}$

Conclui-se, assim, que, para ser cautelar, a tutela deve ser instrumento de uma tutela satisfativa, buscando assegurar sua efetividade, dar ao titular a segurança de que, com o provimento final, poderá fruir de seu direito de maneira útil. A tutela antecipatória se diferencia, e muito, da cautela, por ser satisfativa, ou seja, por garantir ao autor exatamente aquilo que desejava ao propor a ação, num momento anterior à sentença definitiva.

\section{A natureza jurídica das prisões provisórias}

Antes de adentrar na análise da natureza jurídica de cada uma das prisões tidas como cautelares no processo penal, é preciso lembrar de uma controvérsia doutrinária da maior relevância.

Valendo-nos da teoria unitarista, que defende a adoção de uma teoria única para o processo, exposta por exemplo, por Afrânio Silva Jardim ${ }^{13}$, o processo cautelar, conforme já exposto, tem o escopo de garantir a eficácia das providências obtidas principalmente em processos de conhecimento e existe sim no processo penal, apenas não tendo ela um caráter autônomo de processo, sendo, porém, prestada de maneira incidental nos demais processos

Ainda segundo os defensores da teoria unitarista, a aplicação de medida cautelar no processo penal deve respeitar a presença dos pressupostos defendidos pela teoria geral do processo e já explicados linhas acima, quais sejam o fumus boni iuris e o periculum in mora.

Por outro lado, para os defensores de que há, no processo penal, uma teoria geral própria $^{14}$, diversa dos demais processos, não se cabe falar aqui nestes requisitos, mas em outros dois: fumus commissi delicti, enquanto probabilidade da ocorrência de um delito (e

\footnotetext{
${ }^{12}$ Segundo Marinoni: A alteração do Código de Processo Civil foi necessária não apenas em razão das novas situações de direito material, que se mostraram carentes de tutela antecipatória, mas principalmente porque a doutrina e os tribunais não admitiam a prestação da tutela satisfativa fundada em cognição sumária, com base na técnica cautelar. (MARINONI, Luis Guilherme; ARENHART, Sergio Cruz. Curso de Processo Civil Processo Cautelar. V. 4. 2. ed. Revista dos Tribunais: São Paulo, 2008, p. 61).

${ }^{13}$ Sobre a adoção da teoria geral do processo, ver: JARDIM, Afrânio Silva. Não creem na Teoria Geral do Processo, mas ela existe. Disponível em: http://www.conjur.com.br/2014-jul-04/afranio-jardim-nao-creemteoria-geral-processo-ela-existe. Acesso em 15 de julho de 2015.

${ }^{14}$ Cite-se, aqui, como exemplo dos expositores dessa tese Aury Lopes Júnior. Ver: LOPES Jr., Aury. Teoria Geral do Processo é danosa para a boa saúde do processo penal. Disponível em: http://www.conjur.com.br/2014-jun-27/teoria-geral-processo-danosa-boa-saude-processo-penal. Acesso em 15 de julho de 2015.
} 
Revista Eletrônica de Direito Processual - REDP. Volume 16. Julho a dezembro de 2015

Periódico Semestral da Pós-Graduação Stricto Sensu em Direito Processual da UERJ

Patrono: José Carlos Barbosa Moreira. ISSN 1982-7636. pp. 640-663 http://www.e-publicacoes.uerj.br/index.php/redp/index

não de um direito) e o periculum libertatis, visto como o risco derivado do atraso inerente ao tempo que deve transcorrer até que recaia uma sentença definitiva no processo.

O presente trabalho filia-se à primeira posição, contudo, não se pretende aqui exaurir a discussão abordada, apenas justificar a adoção de alguns termos e premissas ao longo deste estudo.

Também em um momento preliminar é importante lembrar que há autores, como Luigi Ferrajoli $^{15}$, que combatem as medidas cautelares pessoais, principalmente a prisão, entendendo-a como ato de força e arbítrio que contradiz o princípio nulla poena sine judicio. O pensamento jusfilosófico do autor é extremamente coerente e respeitado, contudo, para os fins deste trabalho, considera-se a prisão cautelar, nos casos em que ela efetivamente tem a natureza de medida cautelar, como uma "injustiça necessária", como já defendia Carrara ${ }^{16}$.

\subsection{A natureza cautelar da prisão preventiva}

Quando se questiona a natureza cautelar da prisão preventiva, indispensável se faz analisar a presença ou ausência dos dois requisitos básicos de configuração das medidas cautelares, quais sejam o fumus boni iuris e o periculum in mora, bem como de suas características intrínsecas, já analisadas acima.

A partir da análise proposta nesse trabalho será possível concluir que a prisão preventiva tem sim natureza cautelar e garante a utilidade do provimento final do processo penal, contudo, isso não ocorre em todas as suas hipóteses de incidência.

\footnotetext{
$15 \mathrm{O}$ pensamento do autor é traduzido no seguinte trecho: "Penso, ao contrário, que a mesma admissão em princípio da prisão ante iudicium, qualquer que seja o fim que se lhe queira associar, contradiz na raiz o princípio de submissão à jurisdição, que não consiste na possibilidade de detenção apenas por ordem de um juiz, mas na possibilidade de sê-lo só com base em um julgamento. Além disso, toda prisão sem julgamento ofende o sentimento comum de justiça, sendo entendido como um ato de força e de arbítrio. Não há de fato qualquer provimento judicial e mesmo qualquer ato dos poderes públicos que despeite tanto medo e insegurança e solape a confiança no direito quanto o encarceramento de um cidadão, às vezes por anos, sem processo. E é um mísero paralogismo dizer que o cárcere preventivo não contradiz o princípio nula poena sine iudicio - ou seja a submissão à jurisdição em seu sentido mais lato —, pois não se trata de uma pena, mas de outra coisa: medida cautelar, ou processual ou, seja como for, não penal. Com semelhantes trapaças nas formalidades, como veremos na quarta parte, dissolveu-se - em nosso e em outros ordenamentos - a função de tutela do direito penal e o papel mesmo da pena enquanto medida preventiva exclusiva, alternativa a outras medidas certamente mais efetivas mas não tão garantistas." (FERRAJOLI, Luigi Direito e razão: teoria do garantismo penal. São Paulo : Editora Revista dos Tribunais, 2002, p. 446)

${ }^{16}$ CARRARA, Francesco. La prisión preventiva. Rio de Janeiro: Forense, 1982, p. 83 apud POLASTRI, Marcellus. A TUTELA CAUTELAR NO PROCESSO PENAL. 3.ed. Atlas: São Paulo, 2014. P. 168.
} 
Revista Eletrônica de Direito Processual - REDP. Volume 16. Julho a dezembro de 2015

Periódico Semestral da Pós-Graduação Stricto Sensu em Direito Processual da UERJ

Patrono: José Carlos Barbosa Moreira. ISSN 1982-7636. pp. 640-663 http://www.e-publicacoes.uerj.br/index.php/redp/index

Passa-se à análise do primeiro requisito inerente à cautelar, este que fica evidenciado na prisão preventiva a partir da imposição legal de comprovação da existência do crime e de indícios suficientes de autoria ${ }^{17}$.

O direito discutido no processo penal cinge-se, principalmente, à comprovação das elementares do crime, bem como da ligação entre o delito e o acusado, pela ocorrência de dolo ou culpa. É preciso que haja, ao menos, uma probabilidade quanto à autoria do crime para que possa ser decretada a prisão cautelar, baseada em um juízo de verossimilhança realizado pelo magistrado antes da cognição plena.

Não é por outra razão que o artigo 314 do CPP prevê a impossibilidade de decretação de preventiva em caso de, pela prova presente nos autos, ser possível verificar que o agente praticou o crime sob o manto de excludente de ilicitude. Neste caso, não haveria razoes para a prisão provisória, não estando presente o fumus boni iuris.

O grande dilema, porém, circunda os pressupostos autorizadores da prisão preventiva, expostos no artigo 312 do CPP, que configurariam o segundo requisito das cautelares, o perigo da demora do processo. Conforme já explicitado, o perigo deve ser para a utilidade do provimento judicial, ou seja, o único perigo que justifica a prisão cautelar do indivíduo é aquele que ameaça a efetividade do provimento final.

Nessa ótica, encontra-se evidente natureza cautelar na decretação da prisão para garantir a "conveniência da instrução criminal” e para "assegurar a aplicação da lei penal”, isso porque, de fato, se o indivíduo, em liberdade representa um perigo para a apuração da prova por, por exemplo, constranger testemunhas ou ameaça a aplicação da lei penal, por dar indícios razoáveis de que pretende se esquivar de uma eventual pena imposta, demonstrando a possibilidade razoável de fuga, por exemplo, o provimento final, seja ele condenatório ou absolutório encontra-se ameaçado, seja porque a ausência de provas firmes pode esconder a verdade dos fatos, ou porque uma vez proferida a sentença condenatória, ela não será cumprida, por ter desaparecido o acusado ${ }^{18}$.

\footnotetext{
${ }^{17}$ No mesmo sentido se posiciona Afrânio Silva Jardim ao reconhecer que "sem um mínimo de probabilidade de prosperar a pretensão punitiva estatal, a medida provisória tornar-se-ia verdadeiramente odiosa”. (JARDIM, Afrânio Silva. Direito processual penal: 11. ed. - Rio de Janeiro: Forense, 2007).

18 Tourinho Filho também reconhece o inegável caráter cautelar da prisão nessa situação: "Em face do exposto, que tem o apoio da melhor doutrina, chega-se a conclusão inarredável de que a prisão preventiva, pedra de toque de toda e qualquer prisão cautelar, só se justifica quando presente uma

destas circunstancias: "conveniência da instrução criminal" e "asseguramento da aplicação da lei penal”. Desse modo toda e qualquer prisão provisória que supere esse limite e ilegítima, arbitraria, visto que contraria ao princípio da "presunção de inocência", dogma de fé. A prisão preventiva e permitida, única e exclusivamente,
} 
Revista Eletrônica de Direito Processual - REDP. Volume 16. Julho a dezembro de 2015

Periódico Semestral da Pós-Graduação Stricto Sensu em Direito Processual da UERJ

Patrono: José Carlos Barbosa Moreira. ISSN 1982-7636. pp. 640-663 http://www.e-publicacoes.uerj.br/index.php/redp/index

Nestes casos, inegável o caráter de segurança da prisão ${ }^{19}$.

A grande discussão se coloca quanto à natureza cautelar da prisão preventiva, quando estão presentes os requisitos de "garantia da ordem pública" e "garantia da ordem econômica". Vale lembrar que, pela vagueza dos conceitos, muita controvérsia já houve para defini-los.

Parte-se da premissa, neste trabalho, de que a prisão para garantia da ordem econômica só pode ser decretada quando houver a prática de um crime capaz de colocar em perigo a ordem econômica, como exemplo aqueles previstos na lei 8137/90, como bem aponta Tourinho Filho ${ }^{20}$. No mais, todas as considerações feitas quanto à "cautelaridade" da prisão na hipótese de garantia da ordem pública, servirão também ao pressuposto ligado à ordem econômica.

Ao longo do tempo, a preventiva já foi decretada com base na ordem pública com vários tipos de fundamentos, a depender do que, no momento, se tinha como mais "necessário" à repressão dos crimes.

Alguns exemplos podem ser citados com facilidade.

A "gravidade do delito" e a "periculosidade do agente" já foram, durante muito tempo, fundamentos adotados, inclusive pelo Supremo Tribunal Federal ${ }^{21}$, para manutenção da prisão preventiva como garantia da ordem pública. A garantia da "credibilidade das instituições" e o "aumento da confiança da população nos mecanismos oficiais de repressão

para os fins do processo penal." (TOURINHO FILHO, Fernando da Costa. Processo penal, 34. Ed. rev. e atual. - São Paulo: Saraiva, 2012, v. 3, p. 550. )

${ }^{19}$ No mesmo sentido, Gustavo Badaró: "Principia-se pela prisão para "assegurar a aplicação da lei penal". Nesse caso, a prisão é necessária para "evitar que, diante da possível fuga do acusado, pelo temor da condenação, venha a ser frustrada a futura execução da sanção punitiva". $22 \mathrm{O}$ perigo de fuga ocorre quando o investigado ou o acusado "prepara-se para deixar o seu domicílio, desfazendo-se dos bens imóveis, demonstrando o desejo de empreender viagem ou revela a outrem esse seu propósito".23 Trata-se, claramente, de uma hipótese de prisão cautelar pelos fins a que se destina. Assegurar a utilidade e a eficácia de um provimento condenatório que se mostra provável, diante do fumus commissi delicti. Tal situação tem sido denominada como prisão cautelar final.24 Também é cautelar a prisão preventiva decretada "por conveniência da instrução criminal". 25 Sua necessidade surge quando o acusado está ameaçando ou subornando testemunhas ou peritos, ocultando ou destruindo provas, ou buscando furtarse ao comparecimento a atos de instrução em que sua presença seja necessária, como no reconhecimento pessoal. Trata-se de prisão cautelar instrumental.27 Sua finalidade não é diretamente assegurar a eficácia do resultado final do processo em si (p. ex.: evitar a fuga que impediria o cumprimento a sentença), mas sim conservar os meios ou instrumentos (provas) para que se possa chegar a tal resultado (sentença condenatória).” (BADARÓ, Gustavo Henrique Righi Ivahy. A prisão preventiva e a proporcionalidade: propostas de mudança. Revista da Faculdade de Direito da Universidade de São Paulo v. 103 p. 389-390 jan./dez. 2008)

${ }^{20}$ TOURINHO FILHO, Fernando da Costa. Processo penal, 34. Ed. rev. e atual. - São Paulo: Saraiva, 2012, v. 3 , p. 559.

${ }^{21}$ Conferir, como exemplo, o inteiro teor do julgamento: HC 89491, Relator(a): Min. CÁRMEN LÚCIA, Primeira Turma, julgado em 26/09/2006, DJ 20-10-2006 PP-00063 EMENT VOL-02252-03 PP-00454 RTJ VOL-00200-03 PP-01347 LEXSTF v. 29, n. 337, 2007, p. 471-478) 
Revista Eletrônica de Direito Processual - REDP. Volume 16. Julho a dezembro de 2015

Periódico Semestral da Pós-Graduação Stricto Sensu em Direito Processual da UERJ

Patrono: José Carlos Barbosa Moreira. ISSN 1982-7636. pp. 640-663 http://www.e-publicacoes.uerj.br/index.php/redp/index

às diversas formas de delinquência" também já foram argumentos acolhidos pelo Superior Tribunal de Justiça. ${ }^{22}$

Demonstradas as várias hipóteses utilizadas como fundamento da garantia da ordem pública há que se considerar que hoje tem sido adotada como posição majoritária o critério do risco considerável de reiteração criminosa por parte do acusado, caso permaneça em liberdade $^{23}$, o que evidenciaria a periculosidade concreta do agente.

Com a decretação da prisão preventiva como garantia da ordem pública, baseada, segundo a visão mais adotada, na possibilidade de reiteração criminosa, questiona-se: nesta hipótese, a prisão preventiva, decretada durante o inquérito ou processo, serve para conservar alguma situação indispensável para assegurar a utilidade do provimento final? O risco de reiteração criminosa é elemento inerente ao processo como são o perigo para a produção probatória e o risco para a aplicação da lei penal?

Diante de tudo que até aqui já foi exposto, parece claro que, neste caso, a prisão preventiva não acautela o processo penal ao qual está instrumentalmente ligada. Nada tem a ver com ele e com seu resultado final ${ }^{24}$. A possibilidade de reiteração criminosa, o clamor social, a gravidade do crime, a periculosidade do agente e o que mais se venha a incluir no vago conceito de ordem pública, podem servir à sociedade, mas de certo não servem ao processo $^{25}$.

22 Informativo ne 397 do STJ - HC 120.167/PR: “. A garantia da ordem pública não se restringe às medidas
preventivas para evitar conflitos e tumultos, mas abrange também a promoção daquelas providências de
resguardo à integridade das instituições, à sua credibilidade social e ao aumento da confiança da população nos
mecanismos oficiais de repressàso às diversas formas de delinquência. HC 120.167-PR, Rel. Min. Napoleão
Nunes Maia $\quad$ Filho, julgado em 4 em $4 / 6 / 2009$ ”. Nunes Maia Filho, julgado em 4/6/2009". Dispo
www.sti.jus.br/docs internet/informativos/RTF/Inf0397.rtf. Acesso em 17 de julho de 2015.

${ }^{23}$ Apenas alguns exemplos: STJ - HC: 302799 SP 2014/0218800-0, Relator: Ministro GURGEL DE FARIA, Data de Julgamento: 28/04/2015, T5 - QUINTA TURMA, Data de Publicação: DJe 18/05/2015; STJ - RHC: 45752 MG 2014/0048041-9, Relator: Ministra LAURITA VAZ, Data de Julgamento: 06/05/2014, T5 QUINTA TURMA, Data de Publicação: DJe 13/05/2014; STF - HC: 124684 MG, Relator: Min. TEORI ZAVASCKI, Data de Julgamento: 09/12/2014, Segunda Turma, Data de Publicação: DJe-250 DIVULG 1812-2014 PUBLIC 19-12-2014; STF - HC: 108049 SP , Relator: Min. TEORI ZAVASCKI, Data de Julgamento: 19/03/2013, Segunda Turma, Data de Publicação: DJe-061 DIVULG 03-04-2013 PUBLIC 04-04-2013.

${ }^{24}$ No mesmo sentido, Tourinho Filho: Quando se decreta a prisão preventiva como "garantia da ordem pública", o encarceramento provisório não tem o menor caráter cautelar. E um rematado abuso de autoridade e uma indisfarçável ofensa a nossa Lei Magna, mesmo porque a expressão "ordem pública" diz tudo e não diz nada." (TOURINHO FILHO, Fernando da Costa. Processo penal, 34. Ed. rev. e atual. - São Paulo: Saraiva, 2012, v. 3, p. 553).

${ }^{25}$ Cite-se também a posição de Badaró: Em suma, quando se prende para "garantir a ordem pública" não se está buscando a conservação de uma situação de fato necessária para assegurar a utilidade e a eficácia de um futuro provimento condenatório. Ao contrário, o que se está buscando é a antecipação de alguns efeitos práticos da condenação penal. (BADARÓ, Gustavo Henrique Righi Ivahy. A prisão preventiva e a proporcionalidade: propostas de mudança. Revista da Faculdade de Direito da Universidade de São Paulo v. 103, jan./dez. 2008, p. 390). 
Revista Eletrônica de Direito Processual - REDP. Volume 16. Julho a dezembro de 2015

Periódico Semestral da Pós-Graduação Stricto Sensu em Direito Processual da UERJ

Patrono: José Carlos Barbosa Moreira. ISSN 1982-7636. pp. 640-663 http://www.e-publicacoes.uerj.br/index.php/redp/index

Muito pelo contrário, a tutela é conferida no curso do processo e nada tem a ver com

sua segurança. É, portanto, provimento efetivamente satisfativo, que antecipa um dos efeitos do provimento final condenatório buscado pela parte acusadora quando manejou a inicial acusatória. Sendo assim, não há dúvidas de que, nessa hipótese, a prisão preventiva é verdadeira antecipação de tutela e nada tem de cautelar.

Impedir a reiteração criminosa tem condão de prevenção especial, que é função da pena e a antecipação dessa função é antecipação de pena propriamente dita, trata-se de verdadeira execução provisória, o que ocorre também com a garantia da ordem econômica. ${ }^{26}$

Não sendo medida cautelar, mas verdadeira antecipação de tutela, a prisão preventiva nestas hipóteses fere de morte o princípio da presunção de inocência, insculpido no artigo 5, inciso LVII, da Constituição Federal que determina que o sujeito de direitos só pode ser considerado culpado e, complementa-se, cumprir sua pena, depois do trânsito em julgado de sentença penal condenatória. ${ }^{27}$

Simone Schreiber ${ }^{28}$ apresenta brilhantemente a relação entre o princípio da presunção de inocência e as prisões cautelares, explicando que esta garantia incide exigindo que o juiz

\footnotetext{
${ }^{26}$ Expondo a doutrina utilitarista que defende a função de prevenção da pena, Ferrajoli: Coerentemente com o critério de máxima utilidade para o maior número de pessoas, correspondente à primeira das duas versões retroexpostas do utilitarismo penal, todas as doutrinas utilitaristas sempre conferiram à pena um objetivo único, qual seja a prevenção dos futuros delitos, tutelando, assim, a maioria não desviante, e deixando de lado aquele da prevenção das reações arbitrárias ou excessivas, tutor da minoria desviante e daqueles assim considerados, a ponto de justificar a indistinta qualificação das mesmas como doutrinas da "defesa social" em sentido lato. 103 Com efeito, as quatro finalidades preventivas comumente indicadas pelo utilitarismo penal como justificações da pena, quais sejam a emenda ou correição do réu, a sua neutralização ou colocação em uma condição na qual não possa causar mal, o fato de conseguir dissuadir todos os outros de imitar-lo por meio do exemplo da punição ou de sua ameaça legislativa, a integração disciplinar destes com aqueles e o conseqüente reforço da ordem mediante a reafirmação dos valores jurídicos lesados dizem respeito somente à prevenção dos delitos. FERRAJOLI, Luigi Direito e razão: teoria do garantismo penal. São Paulo : Editora Revista dos Tribunais, 2002, p. 212)

${ }^{27}$ Confira-se aqui a posição de Wanderson Gutemberg Soares: "Podemos afirmar que o fundamento da prisão preventiva, tendo por base a ordem econômica tem a mesma natureza que o fundamento na ordem pública. Nesse sentido, ambos os fundamentos, ordem pública e ordem econômica, se apresentam contrários a norma constitucional prevista no art. $5^{\circ}$, inciso LVII, qual seja, o princípio da presunção de inocência [...] Nesses termos, tanto o fundamento que tem por base a garantia da ordem pública quanto o de garantia da ordem econômica, não visam a proteção do processo, o que os descaracterizam como instrumento a favor do instrumento processo. " (SOARES, Wanderson Gutemberg. A adequação da prisão preventiva com a presunção de inocência. Disponível em: http://periodicos.pucminas.br/index.php/DireitoSerro/article/view/1962. Acesso em 15 de julho de 2015). No mesmo sentido, Marcellus Polastri lembra que a prisão, para que se respeite o princípio da presunção de inocência, não pode consistir em antecipação de pena: "Assim, o que não pode é a cautelar prisional se traduzir em uma antecipação de pena, ou seja: impor-se a sanção penal a quem ainda não foi considerado culpado de forma irrecorrível e, assim, por consequência, esta se justifica para fins de assegurar os fins do procedimento penal e, o que ;e importante consignar, sempre que a medida seja necessária." (POLASTRI, Marcellus. A TUTELA CAUTELAR NO PROCESSO PENAL. 3.ed. Atlas: São Paulo, 2014. P. 176)

${ }^{28}$ Por sua relevância para o presente estudo, cita-se, na íntegra, passagem do estudo da autora: "Firmou-se então o entendimento de que a presunção de inocência não impede a decretação das chamadas prisões
} 
Revista Eletrônica de Direito Processual - REDP. Volume 16. Julho a dezembro de 2015

Periódico Semestral da Pós-Graduação Stricto Sensu em Direito Processual da UERJ

Patrono: José Carlos Barbosa Moreira. ISSN 1982-7636. pp. 640-663 http://www.e-publicacoes.uerj.br/index.php/redp/index

demonstre a existência de fumus boni iuris e periculum in mora capazes de justificar a segregação cautelar, o que torna incompatível com o referido princípio as prisões automáticas, obrigatórias, ou que decorram de aspectos ligados exclusivamente ao tipo de crime praticado ou ao modo de atuação do agente, o que nada têm a ver com o resguardo do processo.

Conclui-se que a prisão preventiva, demonstrada a existência do crime e os indícios de autoria, será medida de natureza cautelar apenas quando decretada com fundamento na garantia da instrução ou da aplicação da lei penal, fundamentos intrínsecos ao processo, diretamente ligados ao resguardo do seu resultado útil. Nada tem, porém, de cautelar, quando aplicada com fundamento na garantia da ordem pública ou econômica, demonstrando-se, nestes casos, como verdadeira antecipação de tutela, o que é totalmente incompatível com o princípio constitucional da presunção de inocência.

\subsection{Natureza jurídica da prisão em flagrante}

Discussão acirrada também se dá sobre a natureza cautelar da prisão em flagrante.

Para o processualista Aury Lopes $\mathrm{Jr}^{29}$, a prisão em flagrante tem caráter pré cautelar. Defende o autor que a situação de flagrância, a certeza visual da prática do crime, autoriza aos populares e impõe às autoridades policiais o dever de prender aquele que pratica do delito, colocando o preso à disposição do juízo para que ele decida adotar ou não uma medida cautelar, destinada a resguardar a viabilidade do processo. O flagrante seria um instrumento do instrumento, a prisão preventiva.

Defendendo a natureza efetivamente cautelar da prisão em flagrante, pode-se apontar Tourinho Filho ${ }^{30}$, que entende que, ao exercer o ditame do artigo 310 do Código de Processo

\footnotetext{
processuais (prisão em flagrante, temporária, preventiva, e prisão decorrente da pronúncia e da sentença condenatória recorrível, todas previstas em lei). Não obstante, o princípio incide para exigir que o juiz demonstre a ocorrência de fumus boni iuris e periculum in mora (ou periculum libertatis) a autorizar a decretação da custódia cautelar, significando que não são compatíveis com a norma constitucional as prisões processuais obrigatórias, quais sejam, as que decorrem de forma automática de determinado evento processual, ou ainda do cometimento de crimes graves."(SCHREIBER, Simone. O princípio da presunção de inocência. Disponível em: http://jus.com.br/artigos/7198/o-principio-da-presuncao-de-inocencia. Acesso em 15 de julho de 2015). No mesmo sentido, Marcellus Polastri: "Destarte, é nesse sentido que se deve interpretar o princípio constitucional, ou seja: o impedimento de antecipação da prisão-pena ou imposição automática de prisão, sem verificação dos pressupostos cautelares, mormente o periculum libertatis. (POLASTRI, Marcellus. A TUTELA CAUTELAR NO PROCESSO PENAL. 3.ed. Atlas: São Paulo, 2014. P. 177)

${ }^{29}$ LOPES JR. Aury. Direito Processual Penal. 11. ed. São Paulo: Saraiva, 2013, p. 585/586.

${ }^{30}$ TOURINHO FILHO, Fernando da Costa. Processo penal, 34. Ed. rev. e atual. - São Paulo: Saraiva, 2012 , v. 3, p. 487.
} 
Revista Eletrônica de Direito Processual - REDP. Volume 16. Julho a dezembro de 2015

Periódico Semestral da Pós-Graduação Stricto Sensu em Direito Processual da UERJ

Patrono: José Carlos Barbosa Moreira. ISSN 1982-7636. pp. 640-663 http://www.e-publicacoes.uerj.br/index.php/redp/index

Penal, conforme sua redação atual, rechaçando o magistrado as demais cautelares diversas da prisão e entendendo que, além de legal, a manutenção da prisão é necessária, deve converter o flagrante em prisão preventiva. Para o autor, convolada em preventiva, seria inegável o caráter cautelar da prisão em flagrante.

Afrânio Silva Jardim ${ }^{31}$, à época da 11 edição de seu livro de Direito Processual Penal, em 2007, por sua vez, defendia que com o advento da Lei 6416/77 houve consagração legal do caráter cautelar da prisão preventiva uma vez que seus requisitos de existência se encontram positivados na lei. O fumus boni iuris consistia na existência de uma das hipóteses de flagrâncias previstas no artigo 302 do Código de Processo Penal que autorizam o acautelamento do indivíduo para que cesse a pratica delitiva. O periculum in mora, por sua vez, estaria presente toda vez que, ao cumprir o ditame do artigo 310, o magistrado analisasse a necessidade da prisão, vislumbrando algum dos pressupostos da prisão preventiva. Nesses casos, caberia ao magistrado manter a prisão em flagrante, como cautelar de segurança ao processo. A essa época, portanto, Afrânio Silva Jardim se manifestava pela natureza cautelar da prisão em flagrante, vale repetir.

O mesmo autor ainda deixa clara a sua contraposição à noção de prisão em flagrante como medida pré cautelar, pois, para ele, essa afirmação só permite concluir que o flagrante não é cautelar, mas não diz, para essa corrente, qual seria efetivamente sua natureza.

Contudo, com relação à sua visão sobre a natureza jurídica do flagrante, após a promulgação da lei 12.403/2011, reconheceu o autor uma modificação na situação das coisas. Com a redação atual do artigo 310 do Código de Processo Penal, fica evidente que a conversão da prisão em flagrante em preventiva só deve ocorrer se não forem cabíveis ou suficientes as outras medidas cautelares diversas da prisão. Com isso, fica claro que a prisão em flagrante será desconstituída ou substituída por outra medida e não necessariamente mantida se presentes os requisitos da preventiva, como ocorria anteriormente. Se é assim,

\footnotetext{
${ }^{31}$ Nas palavras do autor: "De uma forma ou de outra, diante do direito constituído, logo após pronunciamento do Ministério Público, deverá o juiz verificar se existem os pressupostos elencados no art. 312 que, como visto anteriormente, caracterizam o periculum in mora. Caso contrário, concederá liberdade provisória ao preso. A existência do fumus boni iuris igualmente deverá ser apreciada nesta oportunidade, à luz do que dispõe o caput do mencionado art. 310 do Código de Processo Penal. Não padece dúvida de que isso importou na consagração legislativa da natureza cautelar da prisão em flagrante.” (JARDIM, Afrânio Silva. Direito processual penal: 11. ed. - Rio de Janeiro: Forense, 2007).
} 
Revista Eletrônica de Direito Processual - REDP. Volume 16. Julho a dezembro de 2015

Periódico Semestral da Pós-Graduação Stricto Sensu em Direito Processual da UERJ

Patrono: José Carlos Barbosa Moreira. ISSN 1982-7636. pp. 640-663 http://www.e-publicacoes.uerj.br/index.php/redp/index

segundo Afrânio Silva Jardim ${ }^{32}$ não mais se pode defender a natureza cautelar desta modalidade de prisão ${ }^{33}$.

Fica claro que os efeitos da prisão em flagrante, diante da nova situação imposta pela

lei 12.403/2011 nunca teriam se feito sentir ou teriam sido verdadeiramente instrumentais à utilidade do provimento final do processo. Sendo assim, não há natureza cautelar. Se a prisão em flagrante não é mantida durante o processo, mas relaxada, substituída ou convertida, o flagrante em si, efetivamente, nada tem de cautelar ${ }^{34}$.

Se a natureza jurídica da prisão em flagrante não é de cautelar, só nos resta novamente concordar com o autor já citado quando defende ser, então, um ato jurídico ${ }^{35}$, ou seja, um ato cujos efeitos jurídicos não estão na esfera de dominação do agente, mas são previamente definidos em lei.

\footnotetext{
${ }^{32}$ Vejamos o mais recente posicionamento: “Antes da reforma de 2011, o antigo parágrafo único do artigo 310 do CPP dispunha que a prisão efetuada em flagrante delito só seria mantida se o juiz verificasse a presença dos requisitos que autorizaria a prisão preventiva, caso estivesse solto o indiciado ou réu. Assim, a manutenção judicial da prisão pressupunha os requisitos das medidas cautelares pessoais. Daí porque sustentamos a natureza cautelar de tal prisão. Entretanto, a atual redação do referido artigo já não mais dispõe desta maneira. Em seu caput, elenca as medidas que o juiz deve efetivar diante do auto de prisão em flagrante (relaxar a prisão ilegal, converter a prisão em flagrante em prisão preventiva e conceder liberdade provisória, com ou sem fiança). A conversão da prisão em flagrante em preventiva somente deve ocorrer se as outras medidas cautelares não se mostrarem adequadas e suficientes. Assim, não mais se exigindo a presença dos requisitos da prisão preventiva para manutenção da prisão em flagrante, não mais sustentamos que a sua manutenção tem natureza cautelar." (JARDIM, Afrânio Silva. Reforma do CPP deve corrigir distorções sobre a prisão e liberdade provisória. Disponível em: http://www.conjur.com.br/2015-mar-01/reforma-cpp-corrigir-distorcoesprisao-flagrante. Acesso em 10 de maio de 2015).

${ }^{33}$ Vale destacar aqui que o autor reconhece algumas hipóteses em que o legislador previu a possibilidade de revogar a liberdade provisória concedida ao réu o que, para Afrânio, faria com que a prisão em flagrante, que existia antes da liberdade provisória, ressurgisse, ainda que por breve espaço de tempo. Seriam as hipóteses previstas nos artigos: 310, parágrafo único, 340 e igualmente 338 e 339 do Código de Processo Penal. (JARDIM, Afrânio Silva. Reforma do CPP deve corrigir distorções sobre a prisão e liberdade provisória. Disponível em: http://www.conjur.com.br/2015-mar-01/reforma-cpp-corrigir-distorcoes-prisao-flagrante. Acesso em 10 de maio de 2015).

${ }^{34}$ Em sentido contrário, Marcellus Polastri entende que a prisão em flagrante ainda permanece como cautelar enquanto o juiz não a convola em preventiva: "Importante é ressaltar que, apesar de a prisão em flagrante ter que ser convolada em preventiva, ela não foi expurgada do CPP, até porque tem previsão constitucional, ou seja, enquanto o juiz não convola em preventiva a prisão subsiste cautelarmente, mesmo precariamente, a título de "prisão em flagrante delito", já ficando detido a este título o investigado." (POLASTRI, Marcellus. A TUTELA CAUTELAR NO PROCESSO PENAL. 3.ed. Atlas: São Paulo, 2014. P. 184)

${ }^{35} \mathrm{Na}$ definição de Caio Mário: "Observa-se, então, que se distinguem o "negócio jurídico" e o "ato jurídico". Aquele é a declaração de vontade, em que o agente persegue o efeito jurídico (Rechtesgeschaft); no ato jurídico stricto sensu. Ocorre manifestação volitiva também, mas os efeitos jurídicos são gerados independentemente de serem perseguidos diretamente pelo agente. Sobre esta distinção, lembram-se, entre outros, Windscheid, Stolfi, Trabucchi, Scognamilio, Santoro Passarelli,Serpa Lopes, Sílvio Rodrigues, Vicente Ráo, Torquato Castro, Soriano Neto, Paulo Barbosa de Campos Filho, Alberto Muniz da Rocha Barros, Fabio de Matia. Todos eles são fatos humanos voluntários. Os "negócios jurídicos" são, portanto, declarações de vontade destinadas à produção de efeitos jurídicos queridos pelo agente; os "atos jurídicos stricto sensu" são manifestações de vontade, obedientes à lei, porém geradoras de efeitos que nascem da própria lei. (PEREIRA, Caio Mário da Silva. Instituições de Direito Civil. Vol. 1. 19. Ed. Rio de Janeiro: Forense, 2001).
} 
Revista Eletrônica de Direito Processual - REDP. Volume 16. Julho a dezembro de 2015

Periódico Semestral da Pós-Graduação Stricto Sensu em Direito Processual da UERJ

Patrono: José Carlos Barbosa Moreira. ISSN 1982-7636. pp. 640-663 http://www.e-publicacoes.uerj.br/index.php/redp/index

Ainda contra a natureza cautelar da prisão em flagrante, deve-se lembrar que uma vez realizada por qualquer do povo ou por autoridade pública e ratificada pela autoridade policial, não há dúvidas de que o flagrante, não é decretado por autoridade judicial, quando muito, esta exerce um controle posterior da prisão. A tutela cautelar, por sua vez, como medida de restrição em busca da segurança do processo deve ser decretada pela autoridade judiciária competente. Assim como cabe à jurisdição à tutela do bem jurídico objeto do processo, cabe a ela também a tutela da segurança e da utilidade do provimento final deste procedimento $^{36}$.

Por tudo que foi exposto, rechaça-se, no presente trabalho, a natureza cautelar da prisão em flagrante, considerando-a mero ato jurídico.

\subsection{A "cautelaridade" da prisão temporária}

Antes de adentrar a análise sobre a natureza jurídica da prisão temporária vale dizer que não serão analisadas aqui críticas sobre a constitucionalidade da medida, por lesão a princípios constitucionais como, por exemplo, o princípio da presunção de inocência, embora sejam elas contundentes.

A prisão temporária, como se fez com as demais modalidades de prisão, também passará pelo filtro dos requisitos e das principais características das medidas cautelares. Para aqueles que defendem a natureza cautelar dessa medida, o fumus boni iuris consistiria na exigência legal de fundadas razões de autoria e participação do investigado em algum dos crimes previstos no artigo $1^{\circ}$, inciso III, da Lei 7960/89.

Quanto a este primeiro requisito, um grave problema já se encontra na legislação que permite que as fundadas razoes de autoria e participação sejam inferidas a partir de qualquer

\footnotetext{
${ }^{36}$ Em reforço, Humberto Theodoro Junior apresenta o juiz como elemento subjetivo indispensável à medida cautelar: "A relação processual envolve elementos subjetivos e objetivos, todos importantes para a consecução final da meta do processo: a justa composição da lide. São elementos "subjetivos", além do juiz que soberanamente representa o poder estatal, as partes envolvidas na lide; e são elementos "objetivos" ora as provas (processo de conhecimento), ora os bens (processo de execução). Todos esses elementos (pessoas, provas e bens) podem, na duração ou demora do processo principal, enfrentar situação de risco de dano, por conduta de um dos litigantes ou por evento ocasional. Para proteção provisória de todos eles, tem cabimento a atuação da função cautelar. Mas essa função não consiste em antecipar solução da lide para satisfazer prematuramente o direito material subjetivo em disputa no processo principal. O que se obtém no processo cautelar, e por meio de uma medida cautelar, é apenas a prevenção contra o risco de dano imediato que afeta o interesse litigioso da parte e que compromete a eventual eficácia da tutela definitiva a ser alcançada no processo de mérito." (JUNIOR, Humberto Theodoro. Curso de Direito Processual Civil. V. II. 49. Ed. FORENSE: Rio de Janeiro, 2014. p. 685)
} 
Revista Eletrônica de Direito Processual - REDP. Volume 16. Julho a dezembro de 2015

Periódico Semestral da Pós-Graduação Stricto Sensu em Direito Processual da UERJ

Patrono: José Carlos Barbosa Moreira. ISSN 1982-7636. pp. 640-663 http://www.e-publicacoes.uerj.br/index.php/redp/index

prova admitida na legislação penal. Não exige a lei a existência de prova de materialidade, da existência do crime, mas de qualquer prova que fundamente um juízo de probabilidade quanto à autoridade delitiva. Não é preciso dizer que os abusos podem saltar dessa incompletude da lei, que vilipendia o já analisado princípio da presunção de inocência, clausula constitucional expressa.

Quanto ao periculum in mora, tem-se a exigência, pela lei, de que o investigado não tenha residência fixa ou não tenha fornecido elementos indispensáveis ao esclarecimento de sua identidade, o que configuraria o risco de não ser encontrado ao longo do processo ou mesmo para cumprir o provimento final ou que tal medida seja imprescindível para as investigações do inquérito.

Sobre esse requisito, estamos com Tourinho Filho ${ }^{37}$ quando analisa que, como a lei não exige a cumulatividade de requisitos, pode ser que a prisão de um indivíduo seja decretada, pois não tenha fornecido elementos suficientes para identificação, mesmo que isso não seja imprescindível às investigações, quando, então, bastaria mera notificação para comparecimento na Delegacia com objetivo de se submeter a procedimentos de identificação ${ }^{38}$.

Pergunta-se: ao longo do Inquérito Policial, quando o magistrado defere a prisão temporária do investigado, por ser imprescindível às investigações policiais ou por não ter ele residência fixa, bem como por não ter sido perfeitamente identificado, tal medida guarda relação com a segurança de um futuro provimento final a ser emanado em um processo penal futuramente instaurado?

Estamos com a posição de que é no caso concreto que essa "cautelaridade" será afirmada ou rechaçada, só devendo ser decretada a medida cautelar quando for efetivamente indispensável a uma das finalidades do processo posterior, podendo ser feita uma breve

\footnotetext{
${ }^{37} \mathrm{Na}$ lição do autor: Não obstante se diga ser possível a decretação da prisão temporária havendo fundadas razoes para supor seja o indiciado autor ou participe, com base em qualquer prova admitida na legislação processual penal, desde que ele não tenha residência fixa ou não forneça elementos necessários para o esclarecimento da sua identidade, indaga-se: se a prisão não é imprescindível as investigações, por que o encarceramento por 5 dias do indiciado sem residência fixa? Se a prisão não é imprescindível as investigações policiais, por que a prisão por 5 dias daquele que "não forneceu elementos necessários ao esclarecimento da sua identidade"? (TOURINHO FILHO, Fernando da Costa. Processo penal, 34. Ed. rev. e atual. - São Paulo: Saraiva, 2012, v. 3, p. 539).

${ }^{38}$ Sobre a desnecessidade de cumulação das hipóteses que configuram o periculum libertatis, Ada Pellegrini Grinover: "Penso, assim, que à presença da condição prevista no inciso III (configurando o fumus boni iuris) é suficiente que se cumule um dos dois requisitos previstos nos incisos I e II (caracterizadores, ambos, do periculum libertatis) ". (GRINOVER, Ada Pellegrini. Limites constitucionais à prisão temporária. Revista Jurídica, Porto Alegre, n. 207, p. 38, jan. 1995).
} 
Revista Eletrônica de Direito Processual - REDP. Volume 16. Julho a dezembro de 2015

Periódico Semestral da Pós-Graduação Stricto Sensu em Direito Processual da UERJ

Patrono: José Carlos Barbosa Moreira. ISSN 1982-7636. pp. 640-663 http://www.e-publicacoes.uerj.br/index.php/redp/index

analogia com os requisitos cautelares previstos para a prisão preventiva, sendo eles devidamente adequados à fase de investigação: a necessidade da prisão para assegurar a aplicação da lei penal ou por conveniência da instrução criminal ${ }^{39}$.

Neste ponto, há que se discordar da visão de Patrícia dos Santos Andrée ${ }^{40}$, seguida por Ada Pellegrini Grinover ${ }^{41}$, de que os requisitos impostos pelo artigo $1^{\circ}$, incisos I e II da Lei 7960/89 são alternativos, configurando, cada um de per si, o periculum in mora. Por óbvio não podemos defender que estes requisitos devam ser sempre cumulativos sob pena de exigir que todo aquele que pratica um dos crimes previstos no inciso III, sendo a liberdade prejudicial para a apuração dos fatos, tenha que ser pessoa de residência desconhecida ou de identidade duvidosa. Não é essa a intenção.

A grande questão é que o inciso I, ao exigir que a prisão seja indispensável à investigação dos fatos configura verdadeiro periculum libertatis, desde que, como já dito, essa indispensabilidade seja justificada por alguma das funções precípuas da investigação que servirá a lastrear o processo. Se, por exemplo, a prisão for indispensável para a obtenção de elementos de informação para a formação da opinio deliciti do Ministério Público, por óbvio, isso servirá à segurança do processo, para que haja efetividade de um provimento final. Vale aqui a analogia, devidamente adequada, com os dois requisitos cautelares da prisão preventiva, como já analisado.

Nunca é demais lembrar que a liberdade do indivíduo deve pôr em risco a segurança do inquérito policial, prejudicando a atuação da autoridade policial, o que, em última análise, prejudica a segurança do processo que eventualmente sobrevenha. Só assim haverá mesmo periculum in mora.

Contudo, a prisão do indivíduo cuja residência ou identidade não são perfeitamente conhecidas só se justifica se essa prisão for também indispensável às finalidades da investigação que servirá a lastrear o processo. Isso porque, a prisão, enquanto medida

\footnotetext{
${ }^{39}$ Idem, p. 36: "Por isso, antes de mais nada, a restrição antecipada do direito de liberdade do acusado deve obedecer aos requisitos necessários para a decretação de qualquer provimento cautelar: o fumus boni iuris, entendido como a plausibilidade do direito invocado pelos interessados na medida cautelar; e o periculum in mora que, no caso de prisão cautelar, se configura como periculum libertatis, ou seja, a demonstração de que a liberdade do acusado pode pôr em risco os resultados do processo, quer com relação ao seu desenvolvimento regular, quer quanto à concreta efetivação da sanção penal que venha afinal a ser imposta."

40 ANDRÉ, Patrícia dos Santos. Prisão temporária: medida cautelar para crimes leves? Revista dos Tribunais, n. 691, p. 396-398.

${ }^{41}$ GRINOVER, Ada Pellegrini. Limites constitucionais à prisão temporária. Revista Jurídica, Porto Alegre, $\mathrm{n}$. 207, p. 35-38, jan. 1995.
} 
Revista Eletrônica de Direito Processual - REDP. Volume 16. Julho a dezembro de 2015

Periódico Semestral da Pós-Graduação Stricto Sensu em Direito Processual da UERJ

Patrono: José Carlos Barbosa Moreira. ISSN 1982-7636. pp. 640-663 http://www.e-publicacoes.uerj.br/index.php/redp/index

excepcional, como fica claro a partir da análise do Código de Processo Penal, em sua redação atual, não pode ser decretada de pronto, para garantir a perfeita identificação.

Nesse sentido se posicionam Aury Lopes Jr. e Marcellus Polastri, que defendem a necessidade de estarem presentes sempre os requisitos previstos nos incisos I e III da Lei 7960/89, sendo que o inciso II, ainda que cumulado com o inciso III, não é capaz, por si só, de representar o periculum in mora. Sua aferição até pode ser complementar, mas não pode ser considerada essencial ${ }^{42}$.

Os procedimentos de identificação, por exemplo, hoje delineados na lei 12.037/09, podem ser equacionados pela Autoridade Policial sem que, para isso, haja necessidade de prisão. Esta, porém, poderá ser necessária se houver também fortes indícios de evasão do indivíduo não perfeitamente identificado, furtando-se à aplicação da lei, o que demonstra a necessidade da prisão para a segurança do provimento final. Só assim se impediria a discrepância citada por Tourinho Filho ${ }^{43}$ em notas anteriores.

Desse modo, depois de todas essas considerações, não se adentrando em outras controvérsias quanto à constitucionalidade da prisão temporária, seria possível "salvar" sua natureza de medida cautelar.

\section{Ainda existem prisões efetivamente cautelares? Algumas conclusões.}

Num sistema não mais baseado no pobre binômio prisão/liberdade, mas que dispõe de uma gama de medidas cautelares diversas, vale questionar se estão superadas as discussões

\footnotetext{
${ }^{42}$ Neste ponto, seguimos a interpretação de Aury Lopes Jr: "Contudo, tanto o inciso I como o inciso III, de forma isolada, não justificam a prisão temporária, somente quando combinados. O inciso II (indiciado sem residência fixa ou não fornecer elementos necessários para sua identificação) é completamente contingencial, ou seja, sozinho não autoriza a prisão temporária e sua combinação apenas com o inciso I ou apenas com o inciso III não justifica a prisão temporária. Mais do que isso, o inciso II acaba sendo absorvido pela "imprescindibilidade" do inciso I, sendo logicamente redundante. Em suma: a prisão temporária somente poderá ser decretada quando estiverem presentes as situações previstas nos incisos III e I. A situação descrita no inciso II apenas reforça o fundamento da prisão, logo, pode haver prisão temporária pela conjugação dos três incisos. Todas as demais combinações não autorizam a prisão temporária. ” (LOPES JR. Aury. Direito Processual Penal. 11. ed. São Paulo: Saraiva, 2013, p. 645). No mesmo sentido expõe Marcellus Polastri que: "Para nós, sempre serão necessários os incs. I e III, uma vez que o primeiro demonstra a necessidade da prisão (periculum libertatis) para o sucesso da investigação, sendo esta a razão primeira do instituto, e o terceiro, como visto, porque, demonstra o fumus commissi delicti. Quanto ao segundo, queremos crer, apesar de demonstrar este, também, o periculum libertatis, não basta, por si só, para, junto com o terceiro requisito, autorizar a prisão, pois sempre deverá ser demonstrada a necessidade para o sucesso da investigação. O agente pode não ter residência ou identificação certa, e a prisão não ser necessária para a investigação, pois, $v$. $g$., já se encontra praticamente concluída. " (POLASTRI, Marcellus. A TUTELA CAUTELAR NO PROCESSO PENAL. 3.ed. Atlas: São Paulo, 2014. P. 213/214).

${ }^{43}$ Op. Cit.p. 16.
} 
Revista Eletrônica de Direito Processual - REDP. Volume 16. Julho a dezembro de 2015

Periódico Semestral da Pós-Graduação Stricto Sensu em Direito Processual da UERJ

Patrono: José Carlos Barbosa Moreira. ISSN 1982-7636. pp. 640-663 http://www.e-publicacoes.uerj.br/index.php/redp/index

sobre a natureza jurídica das prisões tidas hoje como "cautelares" e observar se estas, a saber, a prisão preventiva, a prisão em flagrante e a prisão temporária servem a resguardar a utilidade e a efetividade do provimento final do procedimento penal.

Segundo já analisado, para que se considera uma medida incidental como efetivamente cautelar é preciso que se vislumbre a possibilidade de que uma situação venha a causar dano ao bem jurídico tutelado pelo processo, o que configurará a exigência do periculum in mora, já que, mantendo-se inerte o estado-juiz, a tutela final, mesmo que proferida, não atingirá os escopos buscados pela jurisdição contemporânea.

Além disso, por ser proferida num momento precário, a tutela cautelar deve ser fundamentada na verossimilhança proveniente da plausibilidade das alegações da parte que a requer, configurando-se, assim, o fumus boni iuris, capaz de garantir ao magistrado que, naquele momento, o deferimento da cautelar é a medida mais adequada.

Não se pode esquecer também que, para que se configure efetivamente como medida cautelar, a tutela não pode ser satisfativa, ou seja, não pode ser provimento antecipatório dos efeitos da decisão final, mas deve ser apenas uma tutela de segurança, destinada a resguardar a efetividade do provimento definitivo.

Diante do exposto, as premissas que norteiam o processo cautelar aplicam-se plenamente ao processo penal, ainda que nele as cautelares se mostrem apenas incidentalmente no procedimento.

Verificadas essas premissas, conclui-se que a prisão preventiva tem sim caráter cautelar, mas não em todos os pressupostos previstos no artigo 312 do atual Código de Processo Penal. Havendo provas de materialidade e indícios suficientes de autoria, essa medida extrema poderá ser decretada por conveniência da instrução criminal ou para assegurar a aplicação da lei penal, se, em liberdade, o indivíduo ameaça a produção probatória ou demonstra a disposição a furtar-se à aplicação da lei.

Nesses casos, não há dúvida, o provimento final fica totalmente vulnerado pela liberdade do agente e há que se decretar a prisão como medida de segurança.

O mesmo não se diz com relação à prisão decretada como garantia da ordem pública ou da ordem econômica, isso porque, esses conceitos abertos que hoje, segundo um certo consenso, buscam impedir a reiteração criminosa, nada têm a ver com o bem jurídico tutelado no processo, não buscam a segurança da decisão final, esta que não está ameaçada pela liberdade. O que se busca, nesse caso, é impedir que o indivíduo, em liberdade, volte a 
Revista Eletrônica de Direito Processual - REDP. Volume 16. Julho a dezembro de 2015

Periódico Semestral da Pós-Graduação Stricto Sensu em Direito Processual da UERJ

Patrono: José Carlos Barbosa Moreira. ISSN 1982-7636. pp. 640-663 http://www.e-publicacoes.uerj.br/index.php/redp/index

delinquir, em última análise, o que se busca é antecipar a prisão, um dos efeitos da condenação. E se é assim, a medida é verdadeira antecipação de tutela, que deve ser rechaçada, com base na previsão constitucional da presunção de inocência.

Quanto à prisão em flagrante, não sendo ela decretada por autoridade judiciária, tratase de ato administrativo, que não está ligado a segurança de qualquer procedimento, este que sequer existe quando a prisão é efetuada. Depois de implementada, quando então a situação é submetida ao órgão judicial, a prisão deverá ser relaxada, substituída por outra medida cautelar menos gravosa ou convertida em preventiva, conforme o que prevê o artigo 310 do Código de Processo Penal, sendo certo que ela, a prisão em flagrante, jamais atuou como medida de cautela de qualquer procedimento, sendo, pois, no curto tempo em que existe, mero ato jurídico.

Com relação à prisão temporária, para se afirmar sua natureza cautelar algumas ressalvas precisam ser feitas. O fumus boni iuris deve ser demonstrado de maneira veemente, através de elementos informativos que demonstrem a materialidade de um dos delitos graves previstos no artigo $1^{\circ}$, inciso III, da Lei 7960/1989 e a mínima ligação deste ao indivíduo que se intenta prender. Não se pode esquecer que o ordenamento deve ser visto enquanto sistema e a reforma feita pela Lei 12.403/2011 deixou claro que a prisão é medida excepcional.

Para que o periculum in mora exista, é preciso que a medida seja imprescindível a resguardar as investigações, ou seja, que a liberdade do investigado ponha em risco a obtenção de elementos informativos que servirão para forma o convencimento do titular da ação penal. Para isso, a imprescindibilidade deve ser buscada em elementos próprios do procedimento, como a instrução criminal e aplicação da lei penal, pressupostos da prisão preventiva.

No que tange à previsão do inciso II do artigo $1^{\circ}$, da mesma Lei, não se acredita que ele, sozinho, sirva a configurar periculum in mora capaz de ensejar a prisão, esta que não pode ser decretada apenas porque o indivíduo não foi perfeitamente identificado ou não tem residência fixa. Existem meios menos gravosos de garantir esses objetivos. Só se pode, neste caso, decretar a prisão se esta for realmente imprescindível para as investigações, conforme já explicado acima, o que faz com que a hipótese do inciso II, acabe abarcada pela previsão do inciso I, da Lei 7960/1989. 
Revista Eletrônica de Direito Processual - REDP. Volume 16. Julho a dezembro de 2015

Periódico Semestral da Pós-Graduação Stricto Sensu em Direito Processual da UERJ

Patrono: José Carlos Barbosa Moreira. ISSN 1982-7636. pp. 640-663 http://www.e-publicacoes.uerj.br/index.php/redp/index

Com isso, pode-se concluir que, respeitando a teoria inerente ao processo cautelar e em respeito à técnica que deve nortear o processo, para o alcance das garantias constitucionais por ele buscadas, só se pode considerar efetivamente cautelares a prisão preventiva, com fundamento na conveniência da instrução criminal ou para assegurar a aplicação da lei penal, bem como a prisão temporária, respeitadas as ressalvas feitas neste trabalho.

\section{Referências Bibliográficas}

ANDRÉ, Patrícia dos Santos. Prisão temporária: medida cautelar para crimes leves? Revista dos Tribunais, n. 691, p. 396-398.

BADARÓ, Gustavo Henrique Righi Ivahy. A prisão preventiva e a proporcionalidade: propostas de mudança. Revista da Faculdade de Direito da Universidade de São Paulo v. 103, p. $381-408$, jan./dez. 2008.

BEDAQUE, José Roberto dos Santos. Tutela cautelar e tutela antecipada: tutelas sumárias e de urgência (tentativa de sistematização). São Paulo: Malheiros, 1998.

BOTTINI, Pierpaolo Cruz. MEDIDAS CAUTELARES PENAIS (LEI 12.403/11): Novas regras para a prisão preventiva e outras polêmicas. Revista Eletrônica de Direito Penal. Ano 1. Vol. 1. N. 1. Junho/2013.

BRASIL. Superior Tribunal de Justiça. Habeas corpus 20124 RJ 2006/0189332-7, da $5^{\text {a }}$ turma, Relator: Ministro Felix Fischer, Brasília, DF, 13 nov. 2007. Disponível em: http://stj.jusbrasil.com.br/jurisprudencia/8805765/recurso-ordinario-em-habeas-corpus-rhc20124-rj-2006-0189332-7/certidao-de-julgamento-13889165. Acesso em: 20 jul. 2015.

BRASIL. Superior Tribunal de Justiça. Habeas Corpus 302799 SP 2014/0218800-0, Relator: Ministro Gurgel de Faria, Quinta Turma, Brasília, DF, 28 abr. 2015, Disponível em: http://stj.jusbrasil.com.br/jurisprudencia/189629948/habeas-corpus-hc-302799-sp-20140218800-0. Acesso: 20 jul. 2015.

BRASIL. Superior Tribunal de Justiça. RHC: 45752 MG 2014/0048041-9, Relator: Ministra Laurita Vaz, Quinta Turma, Brasília, DF, 13, mai. 2014, disponível em: http://stj.jusbrasil.com.br/jurisprudencia/25076222/recurso-ordinario-em-habeas-corpusrhc-45752-mg-2014-0048041-9-stj. Acesso: 20 jul. 2015.

BRASIL. Supremo Tribunal Federal. Habeas Corpus 89491, Relator(a): Min. Carmen Lúcia, Primeira Turma, Brasília, DF, 26 set. 2006. Disponível em: 
Revista Eletrônica de Direito Processual - REDP. Volume 16. Julho a dezembro de 2015

Periódico Semestral da Pós-Graduação Stricto Sensu em Direito Processual da UERJ

Patrono: José Carlos Barbosa Moreira. ISSN 1982-7636. pp. 640-663 http://www.e-publicacoes.uerj.br/index.php/redp/index

http://stf.jusbrasil.com.br/jurisprudencia/14731151/habeas-corpus-hc-89491-sp. Acesso: 20 jul. 2015.

BRASIL. Supremo Tribunal Federal. HC: 108049 SP Relator: Min. Teori Zavascki, Segunda

Turma, Brasília, DF, 19 mar. 2013. Disponível em: http://stf.jusbrasil.com.br/jurisprudencia/23090829/habeas-corpus-hc-108049-sp-stf.

Acesso: 20 jul. 2015.

BRASIL. Supremo Tribunal Federal. HC: 124684 MG , Relator: Min. Teori Zavascki,

Segunda Turma, Brasília, DF, 09 dez. 2014. Disponível em: http://stf.jusbrasil.com.br/jurisprudencia/25338394/habeas-corpus-hc-124684-mg-stf.

Acesso: 20 jul. 2015.

DIDIER JUNIOR, Fredie; BRAGA, Paula Sarno; OLIVEIRA, Rafael. Curso de processo civil. Vol. 2, $7^{\mathrm{a}}$ ed. Salvador: Jus Podivm, 2012.

FERRAJOLI, Luigi. Direito e razão: teoria do garantismo penal. São Paulo : Editora Revista dos Tribunais, 2002.

GRECO, Leonardo. Cognição sumária e coisa julgada. In: Revista Eletrônica de Direito Processual, ano 6, v.10, jul./dez. 2012.

GRECO, Leonardo. Garantias Fundamentais do Processo: O Processo Justo. in Estudos de Direito Processual. Campos dos Goytacazes: Faculdade de Direito de Campos, 2005.

GRINOVER, Ada Pellegrini. Limites constitucionais à prisão temporária. Revista Jurídica, Porto Alegre, n. 207, p. 35-38, jan. 1995.

IENNACO, Rodrigo. Reforma do CPP: cautelares, prisão e liberdade provisória. Disponível em: http://www.direitopenalvirtual.com.br/. Acesso em: 11 de maio de 2015. JARDIM, Afrânio Silva. Direito processual penal. 11. ed. - Rio de Janeiro: Forense, 2007. JARDIM, Afrânio Silva. Garantismo no processo penal: breve e parcial reflexão. Revista Eletrônica de Direito Processual, v. 14, p. 6-10, 2014.

JARDIM, Afrânio Silva. Não creem na Teoria Geral do Processo, mas ela existe.

Disponível em: http://www.conjur.com.br/2014-jul-04/afranio-jardim-nao-creem-teoriageral-processo-ela-existe. Acesso em 15 de julho de 2015.

JARDIM, Afrânio Silva. Reforma do CPP deve corrigir distorções sobre a prisão e liberdade provisória. Disponível em: http://www.conjur.com.br/2015-mar-01/reformacpp-corrigir-distorcoes-prisao-flagrante. Acesso em 10 de maio de 2015. 
Revista Eletrônica de Direito Processual - REDP. Volume 16. Julho a dezembro de 2015

Periódico Semestral da Pós-Graduação Stricto Sensu em Direito Processual da UERJ

Patrono: José Carlos Barbosa Moreira. ISSN 1982-7636. pp. 640-663 http://www.e-publicacoes.uerj.br/index.php/redp/index

JUNIOR, Humberto Theodoro. Curso de Direito Processual Civil. V. II. 49. Ed. Rio de Janeiro: Forense, 2014.

LOPES JR. Aury. Direito Processual Penal. 11. ed. São Paulo: Saraiva, 2013.

LOPES JR. Aury. Prisões Cautelares. 4. ed. São Paulo: Saraiva, 2013.

LOPES Jr., Aury. Teoria Geral do Processo é danosa para a boa saúde do processo penal. Disponível em: http://www.conjur.com.br/2014-jun-27/teoria-geral-processodanosa-boa-saude-processo-penal. Acesso em 15 de julho de 2015.

MARINONI, Luis Guilherme. Do processo civil clássico à noção de direito a tutela adequada ao direito material e à realidade social. Disponível na Internet: http://www.abdpc.org.br/abdpc/artigos/Luiz\%20G\%20Marinoni\%20(9)\%20-

\%20formatado.pdf. Acesso em 08 de novembro de 2006.

MARINONI, Luis Guilherme; ARENHART, Sergio Cruz. Curso de Processo Civil Processo Cautelar. V. 4. 2. ed. São Paulo: Revista dos Tribunais, 2008.

PEREIRA, Caio Mário da Silva. Instituições de Direito Civil. Vol. 1. 19. Ed. Rio de Janeiro: Forense, 2001.

POLASTRI, Marcellus. A TUTELA CAUTELAR NO PROCESSO PENAL. 3.ed. São Paulo: Atlas, 2014.

SCHREIBER, Simone. O princípio da presunção de inocência. Disponível em: http://jus.com.br/artigos/7198/o-principio-da-presuncao-de-inocencia. Acesso em 15 de julho de 2015.

SOARES, Wanderson Gutemberg. A adequação da prisão preventiva com a presunção de inocência. Disponível em:

http://periodicos.pucminas.br/index.php/DireitoSerro/article/view/1962. Acesso em 15 de julho de 2015.

TOURINHO FILHO, Fernando da Costa. Processo penal. V. 3, 34. Ed. rev. e atual. - São Paulo: Saraiva, 2012.

WUNDERLICH, Alberto. Princípio da presunção de inocência e a natureza jurídica da prisão preventiva. Disponível em:

http://www.egov.ufsc.br/portal/sites/default/files/anexos/31466-35583-1-PB.pdf. Acesso em 15 de julho de 2015. 